\section{Viktige perspektiver på praktisk veiledning}

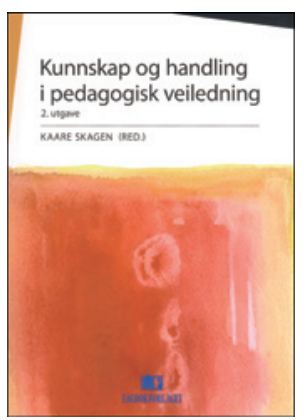

Kaare Skagen, red.

Kunnskap og handling i pedagogisk veiledning

2. utg. 258 s, tab, ill. Bergen: Fagbokforlaget, 2011. Pris NOK 428

ISBN 978-82-450-1196-8

Hovedmålet er å gi leserne kunnskap om teoretiske perspektiver og forskning som kan bidra til å forbedre praktisk veiledning. Boken er en samling artikler beregnet på bruk i studietilbudene i veiledning og lærerutdanning ved universiteter og høyskoler. Den første utgaven har vært i bruk i mer enn ti år, og i denne utgaven er de fleste artiklene beholdt i revidert og oppdatert form.

I innledningen gir bidragsyterne et oversiktsbilde av veiledningstradisjonen i norsk yrkes- og profesjonsutdanning. Deretter følger 12 kapitler (artikler) skrevet av forskjellige forfattere som utdyper veiledningsbegrepet med referanser til sentrale norske og utenlandske teoretikere. Hvert kapittel står på egne bein. En oversiktlig innholdsfortegnelse gjør det enkelt for leseren å velge relevante artikler og begreper man ønsker mer kunnskap om. Kapitlene avsluttes med en omfattende litteraturliste som gir mulighet for utdypende lesing. Språket er klart, og det er flere informative tabeller og figurer.

I kapittel 3 brukes spesialistutdanningen i anestesi som et eksempel for å forklare den viktige grenseoppgangen mellom «læring gjennom deltakelse i praksisfellesskap» (tradisjonell mesterlære) og «læring gjennom reflekterende veiledningssamtaler». Forfatterne Lycke, Lauvås og Handal viser at det er analytisk fruktbart å skille disse situasjonene, men at det er læringsmessig fruktbart å kombinere dem i praksis. For leseren blir det tydelig at god yrkesutdanning må inneholde både ad hoc-veiledning og planlagte reflekterende veiledningssamtaler.

I kapittel 7 understreker Sidsel Tveiten at veiledning er en etisk handling. «Når vi veileder, berører vi en annen. Denne berøringen må være godt ment og basert på kunnskap». For å belyse dette bruker forfatteren et eksempel der fokuspersonen er en sykepleier som mottar veiledning i gruppe med andre sykepleiere på et sykehus. Fokuspersonen har vært plaget av dårlig samvittighet i forhold til oppfølging av en kreftsyk pasient. Gjennom dialog med de øvrige deltakerne i gruppen blir fokuspersonen i stand til å forstå egen praksis. På en levende måte gir dette leseren innsikt $i$ at all veiledning må tilpasses person, situasjon og kontekst.

Styrken er at leseren får innsikt i en rekke sentrale begreper som er knyttet til praktisk veiledning, for eksempel den viktige forskjellen mellom det å være veileder og rådgiver (kapittel 9). I andre kapitler drøfter man mentorbegrepet, coaching, modellæring, stillasbygging, myndiggjøring, reflekterende team etc.

Boken bør være av interesse for alle som driver veiledning, både individuelt og i grupper. For helsepersonell bør den suppleres med litteratur som retter seg mer direkte mot veiledning i helsesektoren.

\section{Svein Steinert}

Nasjonalt senter for distriktsmedisin

Universitetet i Tromsø

\section{En helsethriller om kontroverser, kunnskap og konsekvenser}

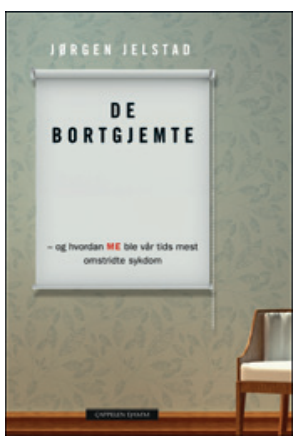

\section{Jørgen Jelstad \\ De bortgjemte}

- og hvordan ME ble vår tids mest omdiskuterte sykdom. 312 s. Oslo: Cappelen Damm, 2011.

Pris NOK 349

ISBN 978-82-02-34863-2

Myalgisk encefalopati, gjerne benevnt ME/CFS, er den mest omstridte sykdommen i det medisinske miljøet de siste 20 årene. Jørgen Jelstads mål er å gi sin forklaring på hvordan det har skjedd. Han spør hvilke konsekvenser fagpersoners holdninger og formidling av disse får for pasientene som står på «bunnen av hierarkiet». Han søker å vise at mange av disse konsekvensene er «usynlige» for folk flest og de som faktisk driver formidlingen.

Målgruppen er først og fremst helsepersonell og helsepolitikere. Boken er samtidig så interessant og lettlest, til tross for en del fagstoff, at den sannsynligvis også vil bli lest av mange pasienter og pårørende.

Jelstad er journalist, fysioterapeut og pårørende til en mor med ME. Ved hjelp av journalistiske metoder har han skrevet om ME/CFS og definisjonsmaktkampen og kontroversene rundt sykdommen. Den grundige kildelisten er 30 sider lang. Jelstad fremsetter konfliktfylt stoff. Hans intensjon er likevel ikke nødvendigvis at leseren skal ha samme oppfatning av virkeligheten han beskriver. Han ønsker diskusjon og et mer nyansert bilde av sykdommen og ME-syke enn hva han mener vi har sett hittil.

Vi får presentert pasienthistorier og skildringer vi ikke forventer å finne i dagens Helse-Norge. Jelstad navngir flere norske forskere. Vi får et innblikk i hvordan forskningsmiljøer fungerer, hvordan beslutninger tas og hvordan en diagnosekamp oppstår og kjempes. I dette ser vi stor fortvilelse blant leger og politikere, som fremstår som handlingslammede.

Forfatteren stiller mange og aktuelle spørsmål rundt bevissthet om egen medisinsk historie, lege-pasient-kommunikasjon, definisjonsmakt og forskningsmiljøer. Boken er høyaktuell. 2011 er utpekt til Vitenskapsåret, høsten 2011 ble det publisert banebrytende, norsk forskning som peker på ME som en mulig autoimmun sykdom (1), og Legeforeningen har satt kommunikasjon, feilbehandling og leger som ledere, på agendaen. Mange har oppdaget at ME-debatten har rast i flere år, og få forholder seg likegyldig til problemstillingene. Nettopp derfor er De bortgjemte viktig.

Selv leser jeg med et sinn med forkunnskaper om temaet. Jeg har vært opptatt av ME og forskning gjennom lang tid, og er sitert. Dette bør likevel ikke føre til at denne anmeldelsen leses som et partsinnlegg.

Jelstad har klart kunststykket å skrive en lettlest bok som man ikke kan legge fra seg, og som i lang tid fremover bør bli diskutert i ulike faggrupper og politiske miljøer. Han ønsker kunnskap fremfor holdninger rundt ME/CFS velkommen.

\section{Maria Gjerpe \\ Oslo}

\section{Litteratur}

1. Fluge $\emptyset$, Bruland $O$, Risa K et al. Benefit from B-lymphocyte depletion using the anti-CD20 antibody rituximab in chronic fatigue syndrome. A double-blind and placebo-controlled study. PLoS One 2011; 6: e26358. 